\section{Entomologists jailed for illegal specimen hunt}

Indian scientists are being asked to help facilitate the release of two Czech entomologists who have been detained in an Indian jail since 22 June.

Petr Švácha, of the Institute of Entomology at the Biology Centre of the Academy of Sciences of the Czech Republic in České Budějovice, and his colleague Emil Kučera were arrested for collecting beetles and butterflies without permission from a national park in West Bengal, in violation of the Indian Biodiversity Act. Arguments are set to be heard on the case on 7 July in Darjeeling.

Although the Indian media has accused them of collecting insects for the Chinese medicine market, the Czechs claim that they were unaware that collecting insects was illegal in India. "These people are sincere, genuine entomologists, and the specimens that they have collected are of no commercial value," says Max Barclay, a senior curator at the Natural History Museum in London, who is calling for their release.

Jan Sula, director of the Czech institute, told Indian authorities that "we believe the incident resulted from misunderstanding as both men did not realize that they had entered the national park".

Leading invertebrate scientists in India are planning to submit a joint petition to the Indian prime minister and the chief minister of West Bengal to free the researchers.

\section{Muslim nuclear physicist sues over freedom of rights}

An Egyptian-born nuclear physicist is suing the US Department of Energy over the revocation of his security clearance.

Moniem El-Ganayni worked from 1990 as a scientist at the Bettis Laboratory, a

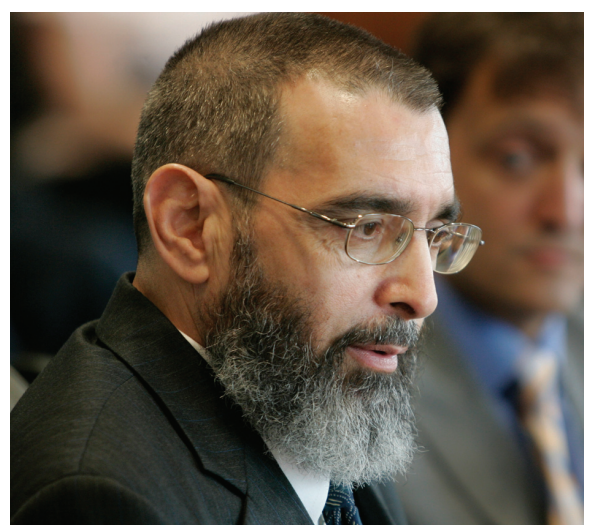

Moniem El-Ganayni is an outspoken critic of the US government. contract lab for the energy department near Pittsburgh, Pennsylvania, that works on nuclear propulsion. El-Ganayni, a US citizen since 1988, is an active member of the local Islamic community. He has been an outspoken critic of the Iraq war and the US government's treatment of Muslims, and was particularly critical of government efforts to recruit informants, according to his lawyer Keith Whitson, a partner at Schnader Harrison Segal and Lewis in Pittsburgh. In May, the energy department revoked El-Ganayni's security clearance, in part because he was suspected of "conflicting allegiances". Shortly thereafter, he was fired from the laboratory. El-Ganayni's suit, filed with the help of the American Civil Liberties Union, claims that the Department of Energy has violated his rights of free speech and freedom from discrimination.

\section{Linnean Society celebrates seminal evolution papers}

This week 150 years ago, papers by British naturalists Charles Darwin and Alfred Russel Wallace were read at the Linnean Society of London, proposing a radical theory that would remove humanity from the centre of creation: the evolution of all life by a process of natural selection. 